\title{
脂肪肉腫に対する放射線併用療法の効果
}

$\begin{array}{ccccc}\text { 長崎大学医学部整形外科 } & & & \\ \text { 平 野 } & \text { 徹 - 岩 崎 勝 郎 } \\ \text { 鈴 木 良 平・浅 田 和 英 } \\ \text { 長崎大学医学部放射線科 }\end{array}$

門 前 芳 夫

\section{Effectiveness of Radiation Therapy in the Treatment of Liposarcoma of Soft Tissue}

by

\author{
Toru Hirano, Katsuro Iwasaki, Ryohei Suzuki \\ and Kazuhide Asada \\ Department of Orthopaedic Surgery, \\ Nagasaki University School of Medicine, Nagasaki
}

\section{Yoshio Monzen}

Department of Radiology, Nagasaki University School of Medicine, Nagasaki

\begin{abstract}
The results of marginal excision and irradiation (3,000 5,000 cGy) in 9 patients with liposarcoma of soft tissue were analyzed to determine the effectiveness of radiation therapy. Only one out of 9 patients, who received $3000 \mathrm{cGy}$, developed a local recurrence at 3 years and 3 months after surgery. The 5 -year actuarial local control rate was $84.7 \%$, which was similar to that by radical and/or curative wide resection in soft tissue sarcomas. In addition, histological examination disclosed that a liposarcoma with preoperative radiation fell into almost necrosis.

It suggests that the combination of conservative surgery and radiation therapy in the treatment of liposarcomas is of use to maintain a functional limb.
\end{abstract}

\section{はじめに}

近年軟部悪性腫瘍に対して患肢温存治療が盛んに行 われている。原発巣に対する治療成績は, 腫痬の組織 学的悪性度や発育態度を考慮した surgical staging system (Enneking) を導入し, 根治的広沉切除術を施 行することにより飛躍的な改善をみている ${ }^{1 / 4)}$. しかし 軟部悪性腫崵が主要血管や神経に近接し術後の患肢機 能を考えると根治的広汎切除術を行うことが困難な症 例や，他施設で不用意な腫瘍摘出術が行われ追加広沉 切除術を行うべきか迷う症例に，しばしば遭遇する。 このような場合，われわれは局所再発を防止する目的 で放射線療法を術前あるいは術後に併用している。
今回，このような治療が行われた軟部悪性腫瘍のう ち，とくに脂肪肉腫に対する放射線併用療法の局所治 療成績について検討したので報告する。

\section{対象症例および方法}

軟部脂肪肉腫の治療として手術的治療と放射線療法 を併用した対象症例は, 1975 年から 1985 年までに 9 例 あった。発症年令は 15 才から 71 才まで分布しており, 平均年令は 52.6 才であった。発生部位は図 1 亿示すご とく，すべて下肢であった．腫瘍の大きさは $10 \mathrm{~cm}$ 末 満が 4 例, $10 \mathrm{~cm}$ 以上が 5 例であり，これらの症例を Enneking の surgical staging system で分類すると, stage IA； 1 例, stage IB；6例, Stage IIA； 1 例 


\section{LOCATION}
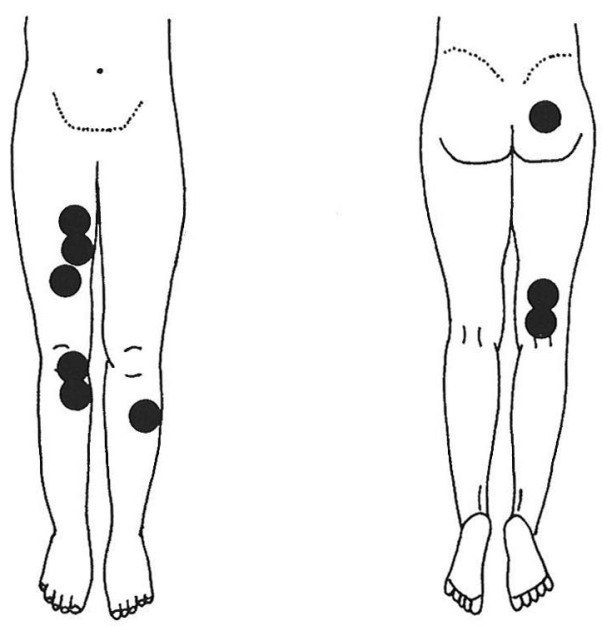

图 1 脂肪肉腫の発生部位を示す。

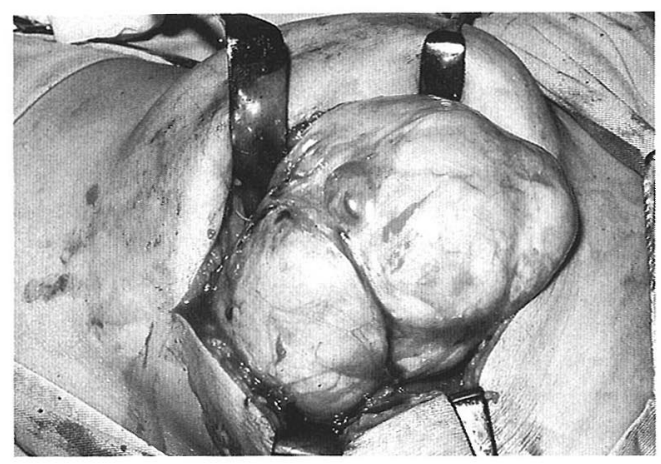

図 241 才, 男性. 樷部発生の巨大な脂肪肉腫例 (stage IB, $19 \times 11 \times 7 \mathrm{~cm}$ ) の手術所見.

および stage IIB；1例からなっていた。

手術法は全例 marginal excision が行われていたが, その理由として, 腫湯が巨大でしかも主要血管・神経 に近接しており根治的広汎切除術を施行すると下肢の 強い機能障害が予想されたためのものが 4 例（図 2 ）, 他施設で良性腫瘍に準じて不用意な腫瘍摘出術をうけ たものが 5 例であった。

以上の症例に対して, 放射線療法として 1 例に術前 照射を， 8 例に術後照射を行った。照射線量は ${ }^{60} \mathrm{Co} \gamma$ 線による 3,000 cGy (TDF 49) が 1 例, $10 \mathrm{MeV}$ Liniac
LOCAL CONTROL

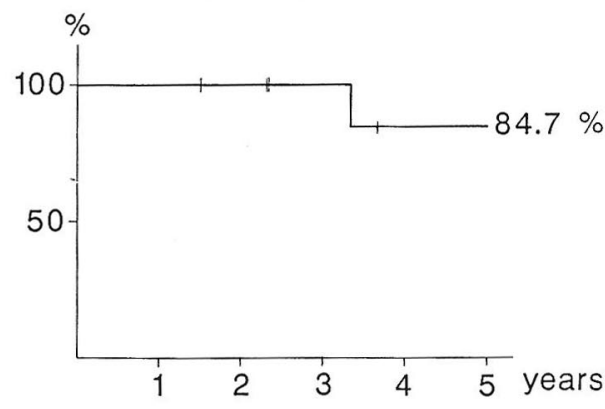

図 3 累積 5 年局所治癒率を示す.

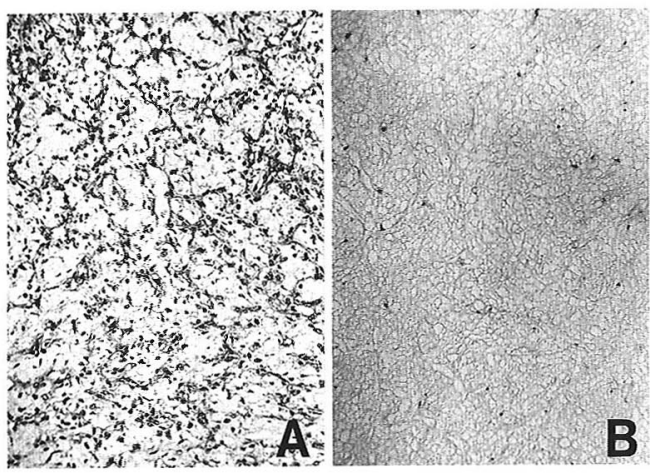

図 $4 \mathrm{~A}$ : 生検組織像. Myxoid liposarcoma の典型 像を示す. $\mathrm{HE}$ 染色, $\times 100$.

B : 放射線照射後. 腫湟組織は全体に壊死化し ていた. HE 染色, $\times 100$.

X 線による 4,000 cGy（TDF 66）および 5,000 cGy (TDF 82) が各々 4 例であった。この治療法の効果を 評価するための累積 5 年局所治瘺率を求め, さらに術 前放射線療法を施行した症例で，照射前・後の組織像 を比較し，放射線照射の有効性を検討した。

$$
\text { 結果 }
$$

2 年以上の経過観察で局所再発は, 他施設で不用意 な手術を施行後, ${ }^{60}$ Co $\gamma$ 線を 3,000 cGy しか照射しな かった stage IB の 1 例で認められた. 再発腫湯に対し て再度 marginal excision を行い, Liniac X線 4,000 cGy の照射を追加した。9例のうち他藏器への遠隔転 移は 3 例にみられた。いずれも腫瘍の大きさは $10 \mathrm{~cm}$ 以 上の症例で, stage IB が 2 例, IIB が 1 例であった。

このシリーズの累積 5 年局所治瘾率は $84.7 \%$ \%゙り, 逆に局所再発率は 15.3 \%であった（図 3 ). 
組織学的に放射線照射の効果を検索した結果，放射 後の腫瘍組織は全体に壞死化しており, viableな腫瘍 細胞はほとんどみられなかった（図4）。

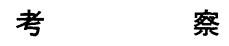

軟部悪性腫瘍の治療成績について, 厚生省軟部悪性 腫瘍研究班のデータによると 1972 年から 1983 年まで の 414 例の局所再発率は $23 \%$ あり, 組織型別には脂 肪肉腫 $21 \%$, 横紋筋肉腫 $27 \%$, 悪性線維性組織球腫 $29 \%$ 滑膜肉腫 $30 \%$ と報告されている 性腫瘍の外科的治療法別の局所再発率について, 川口 は marginal excisionで $80 \%$ 以上なのに対して, 根治 的広汎切除では概ね 10 ないし $20 \%$ であると述べ，そ の有効性を唱えている4). しかし先に述べたごとく，実 際には腫瘍が主要血管や神経に近接し, 根治的広沉切 除術を施行すると著しく患肢機能が障害される症例や 他施設で良性腫瘍に準じた腫瘍摘出術が施行された症 例に遭遇する。このような症例に対して，われわれは 術前あるいは術後に放射線療法を併用し, 患肢機能の 温存を計って来た.

軟部悪性腫瘍に対する放射線併用療法に関して, 手 術単独例よりも治療成績は良好で, 非根治的広汎切除 に放射線照射を併用したものは局所再発率が約 $20 \%$ で あったと報告されている ${ }^{5) 6(8)}$.すなわち軟部悪性腫場に 放射線療法は有効であるが，その組織型や組織亜型に 対する放射線感受性について, 現在まだその見解は定 まっていない. 本研究ではとくに脂肪肉腫に焦点をし ぼって治療成績を検討した結果, 累積 5 年局所治瘠率 は $84.7 \%$ と根治的広汎切除に準じた良好な結果が得ら れた. さらに 4,000 cGy の術前照射例の組織学的検索 で，腫瘍全体がほとんど壊死化していたことは，脂肪 肉腫は放射線感受性が高いとの他家の報告を裏付ける ものであった。

最近, 良性腫瘍に準じて腫瘍摘出術が施行された軟 部悪性腫瘍症例に対して, 追加広汎切除を行い良好な 成績が得られたとの報告もみられるが7), 本研究結果か ら脂肪肉腫では, このような症例において放射線療法 のもっともよい適応と考えられた。

\section{ま と め}

Marginal excision と放射線照射と併用した脂肪肉 腫 9 症例について, 放射線療法の有効性について検討 した.
1. Marginal excision でも 4,000〜5,000 cGy の放 射線照射の併用により累積 5 年局所治癒率は $84.7 \%$ で あったが, これは手術単独例における根治的広汎切除 術の治療成績に相当するものであった。

2. 組織学的に $4,000 \mathrm{cGy}$ の術前照射を行った症例 では腫瘍全体がほとんど壊死化しており，脂肪肉腫は 放射線感受性の高いことを示す所見であった。

3. 以上より marginal excisionなど狭い margin で摘出された脂肪肉腫症例では，放射線療法が再発防 止のためのもつともよい適応と考えられた。

\section{参 考 文 献}

1) Enneking, W. F. et al. : Current concepts review the surgical staging of musculoskeletal sarcoma. J. Bone and Joint Surg., 62-A : 1027-1030, 1980.

2）古屋光太郎：軟部腫瘍の予後. 整形外科 MOOK, 34:141-142, 1985.

3）保高英二・高田典彦：放射線療法. 整形外科 MOOK, $38: 120-132,1985$.

4）川口智義：軟部悪性腫瘍の治療．日整会誌，58：373 $-390,1984$.

5) Lindberg, R. D. et al. : Conservative surgery and postoperative radiotherapy in 300 adults with softtissue sarcomas. Cancer $47:$ 2391-2397, 1981.

6) McNeer, G.P. et al. : Effectiveness of radiation therapy in the management of sarcoma of the soft somatic tissues. Cancer 22: 391-397, 1968.

7）柴田大法・他：Marginal excision 後悪性と診断され た軟部腫瘍に対する追加的広範切除術. 第 15 回日整会, 骨軟部腫湯研究会抄録，48，1986.

8) Suit, H.D. et al.: Preoperative, intraoperative and postoperative radiation in the treatment of primary soft tissue sarcoma. Cancer 55 : 2659-2667, 1985.

\section{質 問鳥取大学 古瀬 清夫}

基本的には私は放射線治療の併用を好みませんが， 時には照射を併用することも事実です．次の点につい て教えて下さい.

(1) 術前照射と術後照射との使い分けについて.

(2) 術前照射有効例の大きさと腫瘍辺縁の組織像に วいて.

(3) 脂肪肉腫については，手術で根治性を得るため には照射の併用が必要であったかどうかについて。

解 答長崎大学 平野 徹

(1) 照射時期について；Marginal excision が出来 
る例では術後照射を行っている，術前照射は intralesional excision になる可能性のある例に限って 行っている.

(2) 脂肪肉腫はもともと他の肉腫に比して局所再発 は起しにくいものではあるが, 厚生省班研の報告でも かなりの再発率を示しており, 今回のわれわれの結果 は放射線療法の効果によるものと考えている.

（3）術前照射を行った症例の腫瘍は $19 \times 15 \times 10 \mathrm{~cm}$ で,腫瘍は全体に壊死化しており,辺縁では pseudocapsule の形成が強かった。

\section{質 問熊大学 米村 憲輔}

Curative or wide excision $と$ marginal excision + radiation とはどちらがベストな治療法と考えられてい るか.

放射線治療後の malignant tumor の発生の危険性 は?

解 答長崎大学 平野 徹

(1) 患肢機能を温存出来, 根治的広切術が行うこと が出来れば，それがもっともよいと思う。

(2) 放射線肉腫について,われわれは 1973 年より現 在の高エネルギーリニアックX線照射を行っているが, 放射線肉腫は一例も経験していない。 